\title{
SPATIAL ANALYSIS FROM REMOTELY SENSED OBSERVATIONS OF CONGO BASIN OF EAST AFRICAN HIGH LAND TO DRAIN WATER USING GRAVITY FOR SUSTAINABLE MANAGEMENT OF LOW LAYING CHAD BASIN OF CENTRAL AFRICA
}

\author{
M. Baba Gana, B. Herbert \\ No. 14, F10 Close, Citec Mbora Estate, Abuja-baanakime@yahoo.com \\ No.1 Eldoret Street, off Aminu Kano Crescent, Wuse 2, Abuja- bhertbert75@yahoo.com
}

KEY WORDS: Analysis, Combination, Environment, land, Management, Observations, Remote sensing, Sustainable.

\begin{abstract}
:
The Chad basin which covers an area of about 2.4 million kilometer square is one of the largest drainage basins in Africa in the centre of Lake Chad .This basin was formed as a result of rifting and drifting episode, as such it has no outlet to the oceans or seas. It contains large area of desert from the north to the west. The basin covers in part seven countries such as Chad, Nigeria, Central African Republic, Cameroun, Niger, Sudan and Algeria it is named Chad basin because $43.9 \%$ falls in Chad republic. Since its formation, the basin continues to experienced water shortage due to the activities of Dams combination, increase in irrigations and general reduction in rainfall. Chad basin needs an external water source for it to be function at sustainable level, hence needs for exploitation of higher east African river basin called Congo basin; which covers an area of 3.7 million square km lies in an astride the equator in west-central Africa-world second largest river basin after Amazon. The Congo River almost pans around republic of Congo, the democratic republic of Congo, the Central African Republic, western Zambia, northern Angola, part of Cameroun, and Tanzania. The remotely sensed imagery analysis and observation revealed that Congo basin is on the elevation of 275 to 460 meters and the Chad basin is on elevation of 240 meters. This implies that water can be drained from Congo basin via headrace down to the Chad basin for the water sustainability
\end{abstract}

\subsection{Introduction}

The shrinking of Lake Chad, is a serious concern especially for the four African countries such as Cameroon, Niger, Nigeria, and Chad republic, which largely embedded on the Chad basin, it is in fact becoming a giant human disaster. The 30 million people who live in the lake region are being forced into everkeener competition for this vital and disappearing resource. The drying-up of the lake water and deterioration of the production capacity of its basin have affected all the socio-economic activities, leading to internal exodus and increased pressure on the natural resources and conflicts between the populations. In addition to the approximately $60 \%$ decline in fish production, there has been degradation of pasturelands, leading to shortage of dry matter estimated at $46.5 \%$ in certain places in 2006, which in turn leading to the reduction in the livestock population in those affected areas. Lake Chad was once one of the largest water bodies on the planet and due to climatic variability, climate change and human pressure on water resources in its basin over recent decades, the lake has shrunk by $90 \%$ from 25000 square kilometer in 1963 to less than 1500 square kilometers in 2001. At the current rate of reduction of the water body, the Lake could disappear about twenty years from now, according to climate forecasts of NASA. The Lake Chad is an endorheic (closed) drainage basin that retains inflow of water but allows no outflow to other bodies such as rivers or oceans. The main river systems flowing into the Lake are those of Yedesram/Ngadda and Hadejia Jama'rareKomadouguo/Yobe from northeast Nigeria. Others are the Logone and Chari located in southwest Chad. The only outlet of water accruing into the Lake drainage basin is by evaporation or underground seepage. Its waters seep into the Soro and Bodele depressions.Most endorheic basins are saline as a result of saltpan occupying their bottom. Examples include the Aral Sea and the Caspian Sea, the world's largest saline body of water. An extreme example is the Dead Sea, which is more saline than the oceans. Australia being very dry with exceedingly low runoff ratios due to ancient soils has significant variable endorheic drainages. These include Lake George originally joined to the Murray-Darling Basin, Lake Corangamite, and Lake Eyre Basin. But the Lake Chad is a freshwater body suggesting a different geological substrate. Located in North Central Africa, Lake Chad covers almost 8 per cent of the continent and spreads over seven countries. It was once Africa's fourth largest lake and the sixth largest in the world, with a maximum length of $25,000 \mathrm{~km} 2$ from a previous $388,500 \mathrm{~km} 2$ some 600,000 years ago. The Lake is generally shallow with only 10.5 meters (34 feet) at its deepest point. Historically, the formation of Lake Chad took place during the Neolithic Sub pluvial period from the 7 th millennium BCE when wet and rainy conditions prevailed in the climate of North Africa. The Lake is believed to be a remnant of the ancient sea, Mega-Chad that grew and shrunk in size with changes in climate over a long period of 13,000 years. The depth of the sea was over 180 meters $(600 \mathrm{ft})$ in most regions and covered over 441, $584 \mathrm{~km} 2(154,400$ square miles) of Central African land before draining into the Atlantic Ocean through the Benue River in present day Nigeria. During this period, which lasted for about 2000 years, large areas of North and Central Africa had hydrographic profiles that were significantly different from 
what obtained later. The existing lake surfaces were several meters higher than what they are today. Lake Chad reached a maximum areal extent of $400,000 \mathrm{~km} 2$, which was larger than the modern Caspian Sea. The surface level was about 30 meters (100 feet) higher than its average in the 20th century. Many of the shallow lakes and river systems that existed during the Sub pluvial era later disappeared and could only be detected today by radar and satellite imagery. Throughout the era, fertile climatic conditions prevailed in North Africa. What is today known as the Sahara desert supported luxuriant savanna type of ecosystem that was habitat to elephants, giraffe and other grassland and wood animals that are found in the Sahel region. The clement fertile conditions supported human settlements in the Nile Valley in Egypt and other Neolithic societies in Sudan.

\subsection{Drain water using gravity from Congo to Chad basin}

Water normally flows from highland to lowland; in this way, Oubangui river can flow with sufficient volume of water to feed the lake Chad from the lower side, particularly as it flows toward the west from the east can feed the Chad basin, and that is why our remotely sensed observation from satellite imagery analysis indicate that difference in elevation along the flowing path is the basic reason for water to flow from Oubangui to Chad basin. Due to Dams construction and other climatic factors like drastic drops in annual rainfalls, Chari River which is the primary source of water to Lake Chad could not supplies water to the Chad basin within the past few decades. Oubangui River flows from the democratic republic of Congo and passes toward south between western boundary of democratic republic of Congo and eastern boundary of republic of Congo to empty its water into the southern Atlantic Ocean via Soyo. The Oubangui River (a tributary of the Congo River) can be dam at Palambo in Central African Republic (CAR) and can subsequently channels some $900 \mathrm{~m}^{3} / \mathrm{s}$ of water annually from the Congo-Oubangui-Sangha Basin, through a navigable canal of about $100-150 \mathrm{~km}$ to Lake Chad via Chari River in Chad republic which formally feeds Lake Chad. Congo Rivers are medium for demarcating international boundaries; one of such example is the Oubangui River, which serves as border between southern boundary of Central African Republic and democratic republic of Congo, and an international boundary between western boundary of democratic republic of Congo and Congo republic. Another instance is the Bahr Auok River, Chari River and Logone River. Bahr River is the boundary between northern democratic republic of Congo and southern Chad republic, from the northern part of Cameroun republic is the Chari River, which are the boundary between Chad republic and the Cameroun republic. When the Oubangui river water is channeled to the Chad basin as being discussed above, the project is expected to restore the ecosystem, rehabilitate the Lake and reconstitute its biodiversity because people will no longer see the need to cut Wood for energy. The canal would facilitate the transport of goods and services in the region. When there is enough water, irrigation will boost agricultural production, fishing as well as reforestation. It is estimated that between 50,000 - 70,000 $\mathrm{km} 2$ of the drainage basin would be put into extensive irrigation. Furthermore, there will be a boost in the region's the energy supply from the 702 megawatts of
By the end of the sub pluvial era around the 4th millennium, drier conditions set in and prevailed. Desertification advanced and the Sahara desert emerged. Since then, arid condition has continued till today, thereby adversely affecting the Lake. The objective of this paper is to investigate the management actions that have been employed to ensure sustainable use of the fragile water body.Experience shows that these shared resources, while serving the needs of the populations across national boundaries often constitute a major source of conflict among the users, as it is the case in the Nile Basin and the Bakassi Peninsular between Nigeria and Cameroon. This underscores the need to study international waters by assessing their uses, abuses, conflicts and to what extent international cooperation have been applied for their sustainable management.

electricity that would be generated from the proposed Oubangui dam.

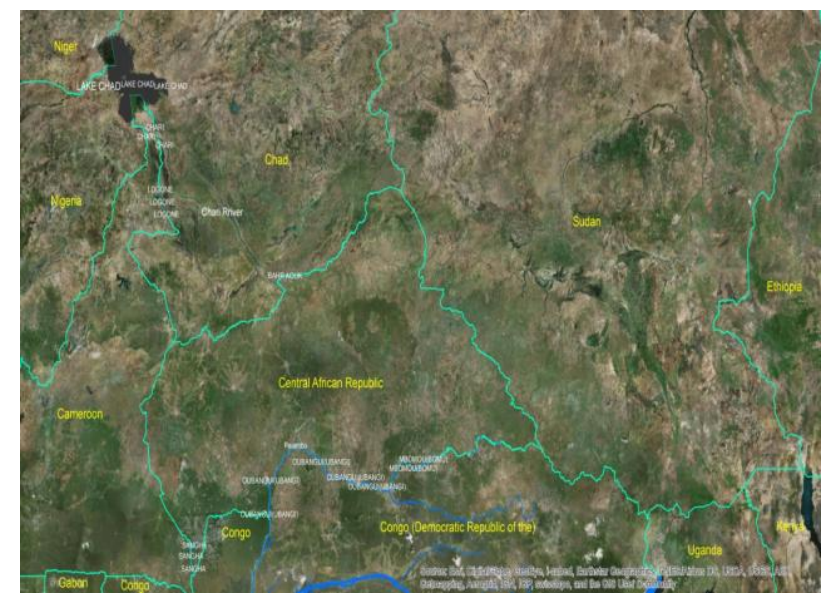

Satellite imagery showing Oubangui River pathway

to Chari River and subsequently to Chad Basin

\begin{tabular}{|l|l|l|l|}
\hline Rivers & \multicolumn{2}{|l|}{ Coordinates } & $\begin{array}{l}\text { Sport } \\
\text { height(m) }\end{array}$ \\
\hline & Latitude & longitude & \\
\hline $\begin{array}{l}\text { Oubangui river at } \\
\text { Palambo }\end{array}$ & 4.35576 & 18.58783 & 491 \\
\hline Chari & 8.84146 & 18.87619 & 359 \\
\hline Lake Chad & 13.31226 & 14.11900 & 282 \\
\hline
\end{tabular}

Table: 1 below illustrates the various coordinates and spot

Height at the Oubangui River (Palambo), Chari and Lake Chad

\subsection{Chad basin}

The Chad Basin is the largest drainage basin in Africa, centered on Lake Chad. It is a poly historic basin that is it has a sagging and moving apart episode with no outlet to the sea that is, it is endorheic (closed), and contains large areas of desert or semiarid savanna. The drainage basin is roughly coterminous with the sedimentary basin of the same name, but extends further to the northeast and east. The basin spans seven countries, including most of Chad and large part of Niger. A combination of dams, increased Irrigation and reduced rainfall are causes for the water shortage and the Lake now continues to experience shrinkage. It has an ethnically diverse population of about 30 million people as of 2011, growing rapidly. The location of Lake Chad on the edge of the Sahara Desert makes it an oasis providing a vital source of water for humans, livestock and wildlife. Domestic water supply and other water-based activities and needs depend heavily on it.The Lake's resources 
benefit an estimated 20 million people living around its shores in the seven basin countries. These include Nigeria, Niger, Algeria, Sudan, Central African Republic (CAR), Chad and Cameroon. As mentioned earlier, four of these countries, namely Nigeria, Chad, Niger and Cameroon have direct contact with the Lake. These countries share about 20 per cent of the Lake Chad Basin called the Conventional Basin, which is under the mandate of the Lake Chad Basin Commission (LCBC).The Lake supports the peasant economy of the local people whose main occupations are fishing, agriculture and pastoralism. A host of fishermen and their families live on the Lake's shores and its islands. Some of the islands include Kalom, Kindjera, Kofia, Kika, Dabouroun, Tebour and Ngelea. Both the annual fish catch from the Lake, fish size and varieties have diminished over time in relation to the dying Lake. In 1972, for example, the annual fish catch was more than 130, $000-141$, 000 metric tons. This has reduced drastically to a current estimated 50, $000-70,000$ tons. Local fishermen report that some 27 years ago, they caught fish as large as man! But this has all changed. Today, the fishermen are grappling with tiny catfish, which is what is available. The average family income has also reduced from about $\$ 100$ a day to a mere $\$ 6$ according to the locals. The common fish species caught in the Lake are Tilapia spp., Schilbe spp., Citharinus citharus, $C$. distichodoides, alestes spp., Labeo coubie., Synodontis spp., and Heterotis niloticus. The resultant environmental changes since the 1970s, including fluctuations in the Lake level have introduced considerable changes in the fish fauna. These include high mortality rate, disappearance of some open-water species and appearance of species adapted to swamp conditions in previously unknown areas. The raising of cattle, sheep and camels by the locals and nomadic herders is an important economic activity. The traditional cultivation of crops has been changing in response to the contraction of the Lake. The villagers have shifted from relying entirely on fishing to farming emergent Lake Floor as water recedes. A few largescale irrigation schemes (polders) developed by the farmers have proven totally unsuited to the hydrological, climatic and cultural conditions in the area. Different crops mainly grains and vegetables are cultivated. These include rice, wheat, barley, guinea corn, onions, lettuce, cucumber and carrots. The devastating droughts that occurred in the 1970s and 80s have had adverse effects on the farming communities and their livelihood system. Droughts have reduced groundwater recharge and have forced farmers to construct poorly designed dams and unsustainable reservoirs leading to inefficient use of water. The worsening dry condition due to lack of rainfall has forced some farmers to abandon farming for other means of livelihood in the nearby cities. Furthermore, the Lake Chad is on a migratory route for birds moving between Africa, Europe and Asia. At least 70 species of birds are known to make stopovers each year. Albeit, the numbers are lower than what was reported in the 1960s, they are still significant and qualify the Lake for inclusion in the Ramsar List of Wetlands of International Importance. Over 120 species of fish have been recorded in the Lake while the flood plains support rich terrestrial and aquatic fauna. The Lake plays important role in regulating annual water supply, recharging groundwater and flood control. Thus, its vast wetland is home to wide varieties of biodiversity.

\subsection{Geology}

The geological basin, which is smaller than the drainage basin, is a Phanerozoic sedimentary basin formed during the plate divergence that opened the South Atlantic Ocean. The basin lies between the West African Craton and Congo Craton, and formed around the same time as the Benue Trough. It covers an area of about 2,335,000square kilometers $(902,000 \mathrm{sq} \mathrm{mi})$. It merges into the Iullemmeden Basin to the west at the Damergou gap between the Air and Zinder massifs. The floor of the basin is made of Precambrian bedrock covered by more than 3,600 meters $(11,800 \mathrm{ft})$ of sedimentary deposits. The basin may have resulted from the intersection of an Air-Chad Trough" running NW-SE and a "Tibesti-Cameroon Trough" running NE-SW. That is, the two deepest parts are an extension of the Benue Trough that runs northeast to the margin of the basin, and another extension running from below the present lake to below The Ténéré rift structure to the east of the Aïr massif. The southern part of the basin is underlain by another elongated depression. This runs in an ENE direction and extends from the Yola arm of the Benue trough. At times, parts of the basin were below the sea. In the northeastern part of the Benue Trough where it enters the Chad Basin there are marine sediments from the Late Cretaceous (100.5-66 Ma). These sediments seem to be considerably thicker towards the northeast. Boreholes under Maiduguri have found marine sediments 400 metres $(1,300 \mathrm{ft})$ deep, lying over continental sediments600 meters $(2,000 \mathrm{ft})$ deep. The sea seems to have Retreated from the western part of the basin in the Turonian (93.5-89.3 Ma). In the Maastrichtian (72.1-66Ma) the west was non-marine, but the southeast probably was still marine. No marine sediments have been found from the Paleocene (66-56 Ma).For most of the Quaternary, from 2.6 million years ago to the present, the basin seems to have been a huge, well-watered plain, with many rivers and water bodies, probably rich in plant and animal life. Towards the end of this period the climate became drier. Around20, 000-40,000 years ago eolianite sand dunes began to form in the north of the basin. During the Holocene, from 11,000 years ago until recently, a giant "Lake Mega-Chad" covered an area of more than 350,000 square kilometers $(140,000 \mathrm{sq} \mathrm{mi})$ in the basin. It would have drained to the Atlantic Ocean via the Benue River .Stratigraphic records show that "Mega-Chad" varied in size as the climate changed, with a peak about 2,300years ago. The remains of fish and molluscs from this period are found in what are now desert regions. The basin in the Nigerian section contains an upper aquifer of Early Pleistocene alluvial deposits that are often covered by recent sand dunes, varying in thickness from 15 to 100 meters (49 to $328 \mathrm{ft}$ ). It consists of interbedded sands, clays and silts, with discontinuous clay lenses. The aquifer recharges from run-off and rainfall. The local people access the water with hand-dug wells and shallow boreholes, and use it for domestic use, growing vegetables and watering their livestock. Below this aquifer, separated from it by a sequence of grey to bluish-grey clays from the lower Pliocene, is a second aquifer at a depth of 240 to 380 meters (790 to1, $250 \mathrm{ft}$ ). Due to heavy pumping, since the start of the 1980s the water levels in both aquifers has been lowered, and some wells no longer function. There is a third, much lower, aquifer in Bima Sandstones that rest unconformably on the basement at a depth of 2,700 to 4,600 meters ( 8,900 to $15,100 \mathrm{ft}$ ). The basin in the Nigerian section contains an upper aquifer of Early Pleistocene alluvial deposits that are often covered by recent sand dunes, varying in 
thickness from 15 to 100 meters (49 to $328 \mathrm{ft}$ ). It consists of interbedded sands, clays and silts, with discontinuous clay lenses. The aquifer recharges from run-off and rainfall. The local people access the water with hand-dug wells and shallow boreholes, and use it for domestic use, growing vegetables and watering their livestock. Below this aquifer, separated from it by a sequence of grey to bluish-grey clays from the lower Pliocene, is a second aquifer at a depth of 240 to 380 metres (790 to 1,250 ft). Due to heavy pumping, since the start of the 1980s the water levels in both aquifers has been lowered, and some wells no longer function. There is a third, much lower, aquifer in Bima Sandstones that rest unconformably on the basement at a depth of 2,700 to 4,600 meters $(8,900$ to 15,100 $\mathrm{ft})$.

\subsection{Drainage basin extent and Rivers}

The Chad Basin covers almost $8 \%$ of the African continent, with an area of about 2,434,000 square kilometers (940,000 sq mi). It is ringed by mountains. The Aïr Mountains and the Termit Massif in Niger form the western boundary. To the northwest, in Algeria, are the Tassili N'Ajjer Mountains, including the 2,158 meters (7,080 ft) Jebel Azao. The Tibesti Mountains to the northof the basin include Emi Koussi , the highest mountain in the Sahara at 3,415 meters $(11,204 \mathrm{ft})$. The Ennedi Plateau lies to the northeast, rising to 1,450 meters $(4,760 \mathrm{ft})$. The Ouaddaï highlands lies the east. They include the Marrah Mountains in Darfur at up to 3,088 meters (10,131 $\mathrm{ft}$ ) in height. The Adamawa Plateau, Jos Plateau, Biu Plateau, and Mandara Mountains lie to the south. To the west the basin is separated by a watershed from the Niger River Basin, and to the south it is separated by a basement dome from the Benue River. Further east, Watersheds separate it from the Congo Basin and the Nile Basin. The lowest part of the basin is not Lake Chad, but the Bodélé Depression, at a distance of 480 kilometers $(300 \mathrm{mi})$ to the northeast of the lake. The Bodélé Depression is just 155 meters (509 ft) above sea level in its deepest portion, while the surface of Lake Chad is 275 metres (902 ft) above sea level. The seasonal Korama River in the south of Niger does not reach Lake Chad. Nigeria includes two sub-basins that drain into Lake Chad. The Hadejia - Jama'are Yobe sub-basin in the north contains the Hadejia and Jama'are rivers, which supply the 6,000 square kilometers (2,300 sq mi) Hadejia-Nguru wetlands. They converge to form the Yobe, which defines the border between Niger and Nigeria for 300 kilometers (190 mi), flowing into Lake Chad. About .5 cubic kilometers $(0.12 \mathrm{cu} \mathrm{mi})$ of water reaches Lake Chad annually. Constructions of upstream dams and growth in irrigation have reduced water flow, and the floodplains are drying up. The Yedseram - Ngadda sub-basin further south is fed by the Yedseram River and Ngadda River, which join to form an 80 square kilometers (31 sq mi) swamp to the southwest of the lake. There is no significant water flow from the swamp to the lake. The Central African Republic (CAR) contains the sources of the Chari and Logone rivers, which flow north into the lake. The volume of water entering Chad annually from the Central African Republic has fallen from about 33 cubic kilometers (7.9 cu mi) before the 1970 s to 17 cubic kilometers $(4.1 \mathrm{cu} \mathrm{mi})$ in the 1980s. A further 3 cubic kilometers $(0.72 \mathrm{cu} \mathrm{mi})$ to 7 cubic kilometers (1.7 cu mi) of water annually flows from Cameroon into Chad via the Logone River. The Chari-Logone system accounts for about $95 \%$ of the water entering Lake Chad. The basin spans parts of seven countries. These are;

\begin{tabular}{|l|c|c|c|c|}
\hline Country & $\begin{array}{c}\text { Indepen } \\
\text { dent }\end{array}$ & $\begin{array}{c}\text { Area within } \\
\text { basin }\left(\mathrm{km}^{2}\right)\end{array}$ & $\begin{array}{c}\% \text { of } \\
\text { total area } \\
\text { of basin }\end{array}$ & $\begin{array}{c}\% \text { of } \\
\text { country } \\
\text { in basin }\end{array}$ \\
\hline Algeria & 1962 & 93,451 & 3.9 & 3.9 \\
\hline Cameroon & 1960 & 50,775 & 2.1 & 10.7 \\
\hline CAR & 1960 & 219,410 & 9.2 & 35.2 \\
\hline Chad & 1960 & 1,046196 & 43.9 & 81.5 \\
\hline Niger & 1960 & 691,473 & 29.0 & 54.6 \\
\hline Nigeria & 1960 & 179,282 & 7.5 & 19.4 \\
\hline Sudan & 1956 & 101,048 & 4.2 & 4.0 \\
\hline Total & & 2,381635 & $100 \%$ & \\
\hline
\end{tabular}

Table 2: Countries and percentage span Lake Chad

\subsection{People and population}

As of 2011, over 30 million people lived in the Chad Basin. The population is growing rapidly. Ethnic groups include Kanuri, Mobber, Buduma, Hausa, Kanembu, Kotoko, Shuwa Arabs, Haddad, Kuri, Fulani and Manga. The largest cities are Kano and Maiduguri in Nigeria, Maroua in Cameroon, N'Djamena in Chad and Diffa in Niger. Humans have lived in the inner Chad Basin from at least eight thousand years ago, and were engaging in agriculture and livestock management around the lake by $1000 \mathrm{BC}$. Permanent villages were established to the south of the lake by $500 \mathrm{BC}$ at the start of the Iron Age. The Chad Basin contained important trade routes to the east and to the north across the Sahara. By the $5^{\text {th }}$ century $\mathrm{AD}$ camels were being used for trans-Saharan trade via the Fezzan, or to the east via Darfur, where slaves and ivory were exchanged for salt, horses, glass beads and, later, firearms. After the Arabs took over North Africa in the 7th and 8th centuries, the Chad Basin became increasingly linked to the Muslim world. Trade and improved agricultural techniques supported more sophisticated societies, leading to the early kingdoms of Kanem, Wadai and Baguirmi. Kanem rose in the 8th century in the region to the north and east of Lake Chad. The Sayfuwa dynasty that ruled this kingdom had adopted Islam by the 12th century. The Kanem empire went into decline, shrank, and in the $14^{\text {th }}$ century was defeated by Bilala invaders from the Lake Fitri region. The Kanuri people led by the Sayfuwa migrated to the west and south of the lake, where they established the Bornu Empire. By the late 16th century the Bornu empire had expanded and recaptured the parts of Kanem that had been conquered by the Bulala. Satellite states of Bornu included the Sultanate of Damagaram in the west and Baguirmi to the southeast of Lake Chad. Abéché , capital of Wadai, in 1918 after the French had taken over The Tunjur people founded the Wadai Kingdom to the east of Bornu in the 16th century. In the 17th century there was a revolt of the Maba people who established a Muslim dynasty. At first Wadai paid tribute to Bornu and Durfur, but by the 18th century Wadai was fully independent and had become an aggressor against its neighbors. To the west of Bornu, by the 15 th century the Kingdom of Kano had become the most powerful of the Hausa Kingdoms, in an unstable truce with the Kingdom of Katsina to the north. Both of these states adopted Islam in the 15th and 16th centuries.Both were absorbed into the Sokoto Caliphate during the Fulani Jihad of 1805, which threatened Bornu itself.During the Conference of Berlin in 1884-85 Africa was carved up between the European colonial powers, defining 
boundaries that are largely intact with today's post-colonial states. On 5 August 1890 the British and French concluded an agreement to clarify the boundary between French West Africa and what would become Nigeria .A boundary was agreed along a line from Say on the Niger to Barruwa on Lake Chad, but leaving the Sokoto Caliphate in the British sphere.Parfait-Louis Monteil was given charge of an expedition to discover where this line actually ran.On 9 April 1892 he reached Kukawa on the shore of the lake. Over the next twenty years a large part of the Chad Basin was incorporated by treaty or by force into French West Africa. On 2 June 1909 the Wadai capital of Abéché was occupied by the French. The remainder of the basin was divided by the British in Nigeria who took Kano in 1903, and the Germans in Cameroon. The countries of the basin regained their independence between 1956 and 1962, retaining the colonial administrative boundaries.

\subsection{Economic Activities}

The main economic activities are farming, herding and fishing. At least $40 \%$ of the rural population of the basin lives in poverty and routinely face chronic food shortages. Crop production based on rain is possible only in the southern belt. Flood recession agriculture is Practiced around Lake Chad and in the riverine wetlands. Nomadic herders migrate with their animals into the grasslands of the northern part of the basin for a few weeks during each short rainy season, where they intensively graze the highly nutritious grasses. When the dry season starts they move back south, either to grazing lands around the lakes and floodplains, or to the savannas further to the south. In the 2000-01 period, fisheries in the Lake Chad basin Provided food and income to more than 10 million people, with a harvest of about 70,000 tons. Fisheries have traditionally been managed by a system where each village has recognized rights over a defined part of the river, wetland or lake, and fishers from elsewhere must Seek permission and pay a fee to use this area. The governments only enforced rules and regulations to a limited extent. Fishery management practices vary. For example, on the Katagum River in Jigawa State, Nigeria, a village will have a water management council That collects a portion of each fisherman's catch and redistributes it among the villagers, or sells it and used the proceeds for communal projects. Local governments and traditional authorities are increasingly engaged in rent-seeking, collecting license fees with the help of the police or army.

\subsection{Climate and ecosystem}

The northern half of the basin is desert, containing the Ténéré desert, Erg of Bilma and Djurab Desert. South of that is the Sahel zone, dry savanna and thorny shrub savanna. The main rivers include riparian forests, flooding savannas and wetland areas. In the far south there are dry forests. [6] Rainfall varies widely from year to year. The amount of annual rainfall is very low in the north of the basin, rising to 1,200 millimeters (47 in) in the south. As late as 2000 , the basin has remained home to large populations of wildlife. In the Sahel these include antelopes such as the addax and dama gazelle, and in the savannah there are korrigum and red-fronted gazelle. The black-crowned crane and other water birds are found in the wetlands. There are populations of elephants, giraffes and lions.
The western black rhinoceros was once common but is now extinct. Elephants almost became extinct by the end of the nineteenth century due to European and American demand for ivory, but stocks have since recovered

\subsection{Factors affecting Chad basin}

There are natural and anthropogenic factors affecting Lake Chad, which account for its predicament. The Lake has been particularly susceptible to increasing variability and irregularity of rainfall during the last four decades. The mean annual rainfall in the basin area is $415-\mathrm{mm}$. Dry spell, excessive evaporation and sandstorm have impacted adversely on the water body. Thus, the Lake has fluctuated greatly over the decades, centuries and millennia to changes in global temperatures and regional rainfall. The water body has shrunk appreciably by up to 80 per cent in 1985 . Today, in absolute terms, the surface area barely reaches $1350 \mathrm{~km} 2$ [2]. The Lake has almost disappeared and is on the verge of extinction. The geographical location of Lake Chad in the arid southern fringes of the Sahara desert is the underlying factor affecting its fragile ecosystem and utilization. All over the Lake basin area, the environmental characteristics are harsh. Extreme high temperatures characterize the Sahara. This is a common phenomenon that induces high evaporation rates of the Lake. The evaporation rate is estimated to be $2000 \mathrm{~mm} / \mathrm{year}$. Low rainfall of about $1500 \mathrm{~mm} /$ year in the south and $100 \mathrm{~mm}$ in the north of the basin is another factor.Thus, from a historic ancient sea referred to as Mega-Chad to the present low ebb almost close to a pond, the Lake Chad has witnessed tremendous changes over time. The changes have however occurred over large time scales caused mainly by fluctuations in climate. Apart from climatic factors, in modern times, human activities have aggravated the disappearance of the Lake. The basin of the Lake extends to over $967,000 \mathrm{~km} 2$ covering five countries that make up the Lake Chad Basin Commission (LCBC). These are Cameroon, Chad, Nigeria and Niger, together with Central African Republic (CAR). About 20 million people, according to the LCBC, populate this area. In the attempt to maximize water resource utilization in an arid environment, the riparian communities in the respective countries harness large amounts of water for irrigation, dam construction, livestock production and other purposes. Fishing is intensively carried out in Lake Chad. Tons of the popular mangana fish consumed throughout West Africa is obtained from the Lake. The excessive use of the Lake water resources by competing demands has put further stress on the strained water body.Thus, as the population demand for water rises, the Lake continues to shrink in size. The Lake's retreat has also been blamed on overgrazing in the area surrounding it, causing desertification and decline of vegetation. Increasing aridity that gave rise to the great Sahelian drought over the past three decades has exacerbated the drying out of the Lake. The surface area of the Lake declined by more than 20 per cent during the West African disastrous Sahelian drought from 1968 - 73. As a result, large quantities of water from the inflowing rivers are being diverted for irrigation purposes before getting into the Lake. It is estimated that over one-third of the waters from River Chari are diverted before reaching Lake Chad. Thus, increased irrigation activity under the cash crop production programme of the various basin countries has impacted adversely on the Lake, especially since the 1980s. The general belief is that about 50 per cent of the decline in the Lake size is attributed to human water use, the remainder is attributed to shifting climate patterns. 


\subsection{Congo basin}

This is the basin of the Congo River, lying astride the Equator in west-central Africa. It is the world's second largest river basin (next to that of the Amazon), comprising an area of more than 1.3 million square miles (3.4 million square $\mathrm{km}$ ). The vast drainage area of the Congo River includes almost the whole of the Republic of the Congo, the Democratic Republic of the Congo, the Central African Republic, western Zambia, northern Angola, and parts of Cameroon and Tanzania. The expression "Congo basin," strictly speaking, refers to the hydrographic basin. This not only is vast but is also covered with a dense and ramified network of tributaries, sub tributaries, and small rivers with the exception of the sandy plateaus in the southwest. The Congo basin is the most clearly distinguished of the various geographic depressions situated between the Sahara to the north, the Atlantic Ocean to the south and west, and the region of the East African lakes to the east. In this basin a fan-shaped web of tributaries Flows downward along concentric slopes that range from 900 to 1,500 feet (275 to 460 meters) in elevation and that enclose a central depression. The basin itself stretches for more than 1,200 miles $(1,900 \mathrm{~km})$ from north to south (from the Congo- Lake Chad watershed to the interior plateaus of Angola) and also measures about 1,200 miles from the Atlantic in the west to the Nile-Congo watershed in the east. The central part of the Congo basin often called the cuvette (literally "saucer" or "shallow bowl") is an immense depression containing Quaternary alluvial deposits that rest on thick sediments of continental origin, consisting principally of sands and sandstones. These underlying sediments form outcrops in valley floors at the eastern edge of the cuvette. The filling of the cuvette, however, began much earlier. Boreholes have revealed that since late Precambrian times (i.e., since at least 542 million years ago) considerable sediment has accumulated, derived from the erosion of formations situated around the periphery of the cuvette. The arrangement of surface relief, thick depositional strata, and substratum in amphitheatre-like fashion around the main Congo channel, which has been uniform across time, is evidence of a persistent tendency to subsidence in this part of the continent. This subsidence is accompanied by uplifting on the edges of the cuvette , principally on its eastern side which has also been influenced by the formation of the Western Rift Valley. The Congo basin is home to the second largest rainforest in the world. The equatorial climate that prevails over a significant part of the Congo basin is coextensive with a dense evergreen forest. The Congolese forest spreads out over the central depression, extending continuously from about $4^{\circ} \mathrm{N}$ to about $5^{\circ} \mathrm{S}$; it is interrupted only by clearings, many of which have a natural origin. The forest region is bordered on either side by belts of savanna (grassy parkland). The forest and savanna often meet imperceptibly, blending together in a mosaic pattern; more rarely, strips of forest invade the grassland. Farther away from the Equator, the wooded savanna region, with its thin deciduous forest, is progressively reached. The basin begins in the highlands of the East African Rift system with input from the Chambeshi River, the Uele and Ubangi Rivers in the upper reaches and the Lualaba River draining wetlands in the middle reaches. Due to the young age and active uplift of the East African Rift at the headlands, the river's yearly sediment load is very large but the drainage basin occupies large areas of low relief throughout much of its area. The basin is a total of 3.7 million square kilometers and is home to some of the largest undisturbed stands of tropical rainforest on the planet, in addition to large wetlands. The basin ends where the river empties its load in the Gulf of Guinea on the Atlantic Ocean. The climate is equatorial tropical, with two rainy seasons including very high rainfalls, and high temperature year round. The basin is home to the endangered western lowland gorilla .The basin was originally the watershed of the Congo River populated by pygmy peoples, but Bantus migrated there from West Africa and eventually founded the Kingdom of Kongo. Belgium, France, and Portugal later established colonial control over the entire region by the late 19th century. Congo is a traditional name for the equatorial Middle Africa that lies between the Gulf of Guinea and the African Great Lakes. It contains some of the largest tropical rainforests in the world. Countries wholly or partially in the Congo region: Angola, Cameroon, Central African Republic, Democratic Republic of the Congo, Republic of the Congo, Burundi, Rwanda, Tanzania and Zambia.

\subsection{Environmental Importance of Congo basin}

The Congo forest is an important biodiversity hotspot. It is home to Okapi, bonobo and the Congo Peafowl, but is also an important source of African teak, used for building furniture and flooring. An estimated 40 million people depend on these woodlands, surviving on traditional livelihoods. At a global level, Congo's forests act as the planet's second lung, counterpart to the rapidly dwindling Amazon. They are a huge "carbon sink," trapping carbon that could otherwise become carbon dioxide, the main cause of global warming. The Congo Basin holds roughly 8 percent of the world's forest-based carbon. These forests also affect rainfall across the North Atlantic. In other words, these distant forests are crucial to the future of climate stability, a Bulwark against runaway climate change. A moratorium on logging in the Congo forest was agreed with the World Bank and the République Démocratique du Congo in May 2002. The World Bank agreed to provide $\$ 90$ million of development aid to RDC with the proviso that the government did not issue any new concessions granting logging companies rights to exploit the forest.The deal also prohibited the renewal of existing concessions. Greenpeace is calling on the World Bank to "think outside the box" and use the forest's potential in the battle against climate change. If these woodlands are deforested, the carbon they trap will be released into the atmosphere. It says that $8 \%$ of the Earth's forest-based carbon is stored in the RDC's forests. Predictions for future unabated deforestation estimate that by 2050 activities in the DRC will release roughly the same amount of carbon dioxide as the United Kingdom has emitted over the last 60 years. The government has written a new forestry code that requires companies to invest in local development and follow a sustainable, twenty-five-year cycle of rotational logging. When a company is granted a concession from central government to 
$\log$ in Congo, it must sign an agreement with the local chiefs and hereditary land owners, who give permission for it to extract the trees in return for development packages. In theory, the companies must pay government nearly $\$ 18 \mathrm{~m}$ rent a year for these concessions, of which $40 \%$ in taxes paid should be returned to provincial governments for investment in social development of the local population in the logged areas. In its current form, the Kyoto protocol does not reward so-called " avoided deforestation" - initiatives that protect forest from being cut down. But many climate scientists and policymakers hope that negotiations for Kyoto's successor will include such measures. If this were the case, there could be a financial incentive for protecting forests. L'Île Mbiye in Kisangani is part of the Sustainable Forest Management in Africa Symposium project of forest ecosystem conservation conducted by Stellenbosch University. République Démocratique du Congo (RDC) is also looking to expand the area of forest under protection, for which it hopes to secure compensation through emerging markets for forest carbon. The main Congolese environmental organization working to save the forests is an NGO called OCEAN, which serves as the link between international outfits like Greenpeace and local community groups in the concessions.

\subsection{Sustainable Management of Chad basin}

There is an observation that, the two sources of the water, that is, the River Chari and River Logone recharging the Lake Chad has been significantly reduced in its water supply, within the few decades. Chad basin needs an external water source for it to be function at sustainable level, hence needs for exploitation of higher east African River basin called Congo basin. A number of actions have been initiated at local, national and international levels to manage the diminishing water resources of Lake Chad. This demonstrates the level of concern by the people, governments of the riparian states and the international community towards the Lake. Most of these actions are ongoing and are generally aimed at reversing the trend towards extinction.

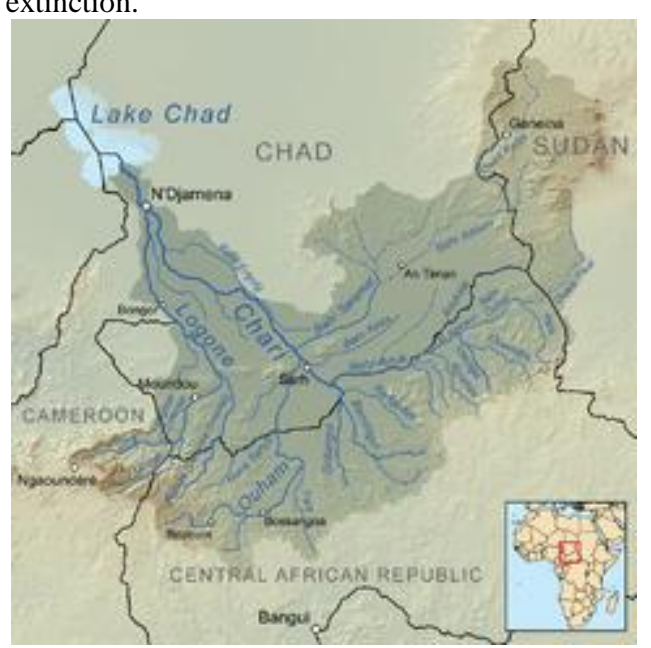

Figure: 2 Locations of Chari and Logone Rivers In the Chad basin

\section{Conclusion}

Dam construction and some other climatic factor hinder Chari River which is the major source water, to feed the Lake Chad. River Oubangui which is major tributary of Congo basin can recharge the Chad basin, the difference in elevation is the bases for water from Congo basin to flow down to Chari lake and subsequently to Chad basin. Chad basin pans around seven African countries of and the larger percentage is in Chad republic as such it is named Chad basin. The basin has a population of over 30 million people and ethnic groups are Kanuri. Shuwa Arabs, Kanembu, manga, mobber Fulani and Buduma. Their major economic activities are farming, fisheries and herding. The basin provides food and income security to more than 10 million people with harvest of over 70,000 tons. There is an observation that lake Chad basin has significantly reduced in its water content, hence need for external water source from Congo basin via chari river in Chad republic to revive the basin' We have attempted in this paper to highlight some of the main issues at stake pertaining to the Lake Chad. The factors affecting the Lake are mentioned. The importance of the Lake in sustaining livelihood systems in a harsh arid ecosystem is stated. The predicament of the Lake and the uncertainty of its future existence are expressed. There is growing consciousness and concern at local, national and international levels over the fate of the Lake and the dependent population. It is on this basis that efforts are being made to apply different management strategies to recover the Lake. The locals are devising various farming and fishing methods to adapt to the changing situation. At the national level, some actions have been initiated to manage the diminishing Lake resources. The international community has also come up with a number of programmes to complement regional efforts. All the actions are geared towards restoring the Lake for sustainable use. Unfortunately,these efforts have not yet yielded any appreciable result as the Lake keeps decreasing rapidly at alarming rate. Inadequate funding has largely hampered the efforts. The other is lack of political will and commitment by the riparian states. The future of the Lake depends on how much the proposed recovery projects and programmes are implemented. This again will depend on funding, which the Member States of the Lake Chad Basin Commission could hardly afford. The Lake Chad Replenishment Project is certainly the most ambitious and vibrant intervention that has the potential to bring life back to the Lake. Consequently, a deliberate and concerted international action is required to give financial impetus to the proposed action plan. There is need to coordinate all the efforts to save the Lake and save the millions of peasant population depending on it for livelihood. The Lake Chad Vision for 2025 identified three major objectives, namely: maintenance of Lake Chad and other wetlands of the region at sustainable levels for the economic security of the freshwater ecosystem resources, sustained biodiversity and aquatic resources of the basin and their equitable use and the alleviation of poverty; acceptance of responsibilities for freshwater, ecosystem and biodiversity conservation and judicious integrated river basin management by regional and national authorities; and (iii) equitable access by Member States to safe and adequate water resources to meet their needs and rights [6]. All the stakeholders at all levels should join hands and work together to realize these objectives for the restoration of the Lake and preservation the ecosystem.

\section{References}

Appiah, Kwame Anthony; Gates, Henry Louis, Jr. (2010). Encyclopaedia of Africa . Oxford University Press. p. 254. ISBN 978-0-19-533770-9 . Retrieved 2013-05-06. 
"Chad Basin" . Encyclopedia Britannica . Retrieved 2013-05-05.

Decorse, Christopher R. (2001). West Africa During the Atlantic Slave Trade: Archaeological Perspectives . Continuum International Publishing Group. ISBN 978-0-7185-0247-8 . Retrieved 2013-05-06.

Falola, Toyin (2008-04-24). A History of Nigeria . Cambridge University Press. ISBN 978-1-139-47203-6 . Retrieved 2013-05-06.

"Geography" . Lake Chad Basin Commission. Retrieved 2013-05-05.

Harlow, Barbara (2003). "Conference of Berlin (18841885)" . Colonialism. ABC-CLIO.

ISBN 978-1-57607-335-3 . Retrieved 2013-05-06.

Haruna, Ahmed Isah; Maigari, A. S.; Tahir, M. L.; Y. D. Mamman, R. B. Gusikit (2012-12-21). Detrital Gypsum Forms in the Nigerian (Southern) Sector of Chad Basin: A Criteria for interpretation in Nigeria's inland basins: Implication of Detrital Gypsum Forms in Sedimentary Basins . GRIN Verlag. ISBN 978-3-656-33912-0 . Retrieved 2013-05-06.

Hirshfield, Claire (1979). The diplomacy of partition: Britain, France, and the creation of Nigeria, 18901898 . Springer. ISBN 90-247-2099-0 . Retrieved 2010-10-10.

Kenmore, Peter Ervin (2004). The Future is an Ancient Lake: Traditional Knowledge, Biodiversity and Genetic Resources for Food and Agriculture in Lake Chad Basin Ecosystems . Food \&amp; Agriculture Org. p. 215. ISBN 978-92-5-105064-4 . Retrieved 2013-05-06.

Lengyel, Emil (2007-03-01). Dakar - Outpost of Two Hemispheres . Simon \&amp; Schuster. ISBN 978-1-4067-6146-7 . Retrieved 2013-05-06

Mazenot, Georges (2005). Sur le passé de l'Afrique Noire . Editions L'Harmattan. p. 352.

ISBN 978-2-296-59232-2 . Retrieved 2013-05-06.

Obaje, Nuhu George (2009-08-12). Geology and Mineral Resources of Nigeria . Springer. p. 69. ISBN 978-3-540-92684-9 . Retrieved 2013-05-06.

Rangeley, Robert; Thiam, Bocar M.; Anderson, Randolph A.; Lyle, Colin A. (1994). International river basin organizations in Sub-Saharan Africa . World Bank Publications. ISBN 978-0-8213-2871-2 . Retrieved 2013-05-06.

Schuster, Mathieu; Roquin, Claude; Duringer, Philippe; Brunet, Michel; Caugy, Matthieu; Fontugne, Michel; Mackaye, Hassan Taïsso; Vignaud, Patrick; Ghienne, Jean-François (September 2005). "Holocene Lake MegaChad palaeoshorelines from space" . Quaternary Science Reviews 24 (16-17). doi : 10.1016/ j.quascirev.2005.02.001 . Retrieved 2013-05-06.
"The Lake Chad basin" . FAO. Retrieved 2013-05-05.

Udo, Reuben K. (1970). Geographical regions of Nigeria . University of California Press. GGKEY:7F4FLYR0FS5. Retrieved 2013-05-06.

Wright, J.B. (1985-11-30). Geology and Mineral Resources of West Africa . Springer. p. 94. ISBN 978-0-04-556001-1 . Retrieved 2013-05-06.

Mineral deposits \& Earth evolution. Geological Society.

2005. ISBN 978-1-86239-182-6

\section{The Fight to Save Congo's Forest.}

Coe, Michael T, Foley J.A. (2001), "Human and natural impacts on the water resources of the Lake Chad Basin”, Jour. Of Geophisical Research, 106 (D4): 3340-3356.

Lake Chad vision for 2025 presented at the Second World Water Forum 2000; UNEP/DEWA 2004 